\title{
Performance-Based Budgeting Review from Local Government Budget: West Sumatra in 2017-2018
}

\author{
Dyah Mutiarin $^{1}$, Aqil Teguh Fathani ${ }^{2}$, Sakir ${ }^{3}$, Muhammad Eko Atmojo ${ }^{4}$ \\ ${ }^{1}$ Master Program of Government and Administration, Universitas Muhammadiyah Yogyakarta, Indonesia \\ ${ }^{2} J$ usuf Kalla School of Government, Universitas Muhammadiyah Yogyakarta, Indonesia \\ ${ }^{3}$ Government Science Study Program, Universitas Muhammadiyah Yogyakarta, Indonesia \\ ${ }^{4}$ Government Science Study Program, Universitas Muhammadiyah Yogyakarta, Indonesia \\ ${ }^{1}$ Corresponding Author: dyahmutiarin@umy.ac.id
}

\section{Article Info}

Keyword:

Spending Review;

Performance Based

Budgeting;

Annual Budget.

Kata Kunci:

Ulasan Pengeluaran;

Penganggaran

Berbasis Kinerja;

Anggaran Tahunan.

\begin{abstract}
The purpose of this article is to analyze the impact of the implementation of Spending Review using Performance-Based Budgeting (PBB) on the APBD (Regional Budget Revenues and Expenditures) of West Sumatra province the year 2018. This article uses the qualitative method to identify and interpret the Spending Review context that needs to be thoroughly identified. The result data were drawing through data codification, data presentation, and the result of data research. This research showed that the condition of the West Sumatra province's regional spending budget for the year 2018 was increasing. However, judging from the indirect expenditures budget of West Sumatra province was declining. Further, on the review of allocation result that has been done against the realization of regional expenditures budget, there were budget savings from the year 2017 - 2018. Then for indicator and performance review through health and education services showed an increased value of human development. Further on, the need deviation analysis showed that within two years of the government budget of West Sumatra province, i.e., the year 2017-2018, it has the rate level of need deviation with the allocation of spending budget $15.56 \%$.
\end{abstract} Abstrak: Tulisan ini bertujuan untuk menganalisis dampak pelaksanaan Review
Belanja dengan Anggaran Berbasis Kinerja (PBB) terhadap APBD (Anggaran
Pendapatan dan Belanja Daerah) Provinsi Sumatera Barat tahun 2018. Artikel ini
menggunakan metode kualitatif untuk mengidentifikasi dan menginterpretasikan
konteks yang terkait dengan Spending Review yang perlu diidentifikasi secara
menyeluruh dalam analisis mendalam. Pengumpulan data hasil melalui kodifikasi
data, penyajian data dan hasil penelitian data. Hasil penelitian menunjukkan
bahwa kondisi APBD Provinsi Sumatera Barat tahun 2018 mengalami peningkatan,
namun dilihat dari APBD Provinsi Sumatera Barat mengalami penurunan.
Selanjutnya pada review hasil alokasi yang telah dilakukan terhadap realisasi
anggaran belanja daerah terdapatpenghematan anggaran daritahun $2017-2018$.
Kemudian untuk indikator dan review kinerja melalui pelayanan kesehatan dan
pendidikan menunjukkan adanya peningkatan nilai pembangunan manusia.
Selanjutnya analisis deviasi kebutuhan menunjukkan bahwa dalam dua tahun
anggaran pemerintah Provinsi Sumatera Barat yaitu tahun 2017-2018 memiliki
tingkat penyimpangan kebutuhan dengan alokasi anggaran belanja sekitar
15,56\%.

Article History: Received: 2020-04-21, Revised: 2020-06-13, Accepted: 2020-09-12 


\section{INTRODUCTION}

After the Reformation period in Indonesia in the years 1998-1999, it has impacted the need for transparency in all government management sectors, including the transparency in the regional finance management (Ledo \& Aye, 2017). This matter was viewed by (Pratama, Abdurahim \& Sofyani, 2018) that budget transparency is still becoming the main problem in the public sector, especially on the regional government management. It was mentioned from (www.kompas.com, 2017), which evaluated the current regional government management as C point (average). Therefore, the growing demands to increase the performance was quite needed in response to the various matter, i.e., the quality of public services, the transparency, and the public accountability that enhance the regional government to implement the performance-based budgeting system up to its maximum effort (Wijayanti, Rahman \& Nurpratiwi. 2012). The less maximum of the regional government effort in the finance management mostly happened because there was still less understanding of the performance budgeting process, especially on the determination of performance indicator filled in the Budgeting Working Plan (Pratama et al.,2018). In contrast, these process demanded the regional government party to be able to execute the determination of those indicators, so it will be able to give more room on the economizing the budgets in several sectors that were considered before having the inefficiency in the certain budget (Nurfauziya, Prakosa \& Kusuma, 2018).

Since 2013, the Indonesian government has started spending review to identify the expenditures inefficiencies and extended the fiscal room (Parhusip, 2016). (Luthfia \& Siregar, 2016) purposes of preventing inefficiency in government budget usage that cannot be controlled by the government that has a negative impact and its insignificance on the program implementation. According to Rachmandiansyah (Rachmandiansyah, 2015), spending review was considered the mechanism to overcome the budgeting planning problem and budget implementation problem. Moreover, according to (Octariani, 2017), the said problem was meant when the government experienced uncontrollable output management and not according to the preliminary planning process. It will need a certain technique in preparing the observation mechanism on budgeting. In conclusion, this technique can increase the effective and efficient budget, and it can be used as expenditures/spending or increasing the budget in other sectors (Robinson, 2013).

Further, the application of the spending review in Indonesia helped find the best budget efficiency choices by improving the current budget quality (Parhusip, 2016).

Further, the implementation of Law no. 32/2004 about the Regional Government and Law no $33 / 2004$ on the Financing Balance between Central government and Regional government has had a significant impact on the government relationship to arrangement state finance management. This is especially on budget management in the region area. In contrast, the making process of APBD (Regional Government Revenues and Expenditures) is arranged based on the performance approach and budget system. In contrast, the output was pointed out primarily on the work result achievement from the planning of allocation budget that has been stated (Verasvera, 2016). So, these acts will create the achievement in work performance that was done by putting attention on the ability of the expendable finance resources and the output from the planning activities program, which is well-known as the term "Performance-Base Budgeting" (ABK). In contrast, these arranged budgets were oriented to the performance target (Dwiputrianti \& Suharsini, 2012).

This Performances-Based Budget was made based on the Annual Work Plan (RKT = Rencana Kerja Tahunan) adopted into the budget Work Plan (RKA=Rencana Kerja Anggaran). RKT and RKA are used to create an effective and efficient usage of the current budget resources that lead to the achievement of activities result (Dwiputrianti \& Suharsini, 2012). So, this Performance-Based Budgeting prioritized the effort to achieve work resulting from the expenditures allocation planning stated (Sudaryanti, 2013). Therefore, implementing good Performance-Based Budgeting will better impact such government organizations (Safarudin \& Basri, 2016). The effectiveness of performance-based budgeting has good implications in budget absorption (Pratama et al., 2018). 
Hence, the absorption of Performance-Based Budgeting can significantly change the budget arrangement suitable to its needs so that budgeting will become more effective and efficient (Astutiningrum, Djamhuri \& Prihatiningtias, 2014). Besides, the government's regional finance management will be more economical and efficient after using Performance-Based Budgeting (Kurrohman, 2013). Further, the regional government's successful effort in managing regional financing will show how good the regional government's work is in managing financial performance (Sari \& Mustanda, 2019). So, this Performance-Based Budgeting was a budgeting system that connected the output and outcome that will be achieved by stressing out the effectiveness and efficient allocation of budgeting usage (Nanda \& Darwanis, 2016).

\section{Data}

Budget is the statement related to estimating the performance that will be reached in a certain period shown in financial measurement (Nanda \& Darwanis, 2016). So, the budgeting in the government sectors is the responsibility of the public fund's Management with work programs or activities using public funds (Pratama et al., 2018). According to the Indonesian Government Regulation number 58 the year 2005 about the Regional Financial Management, the execution of regional expenditures were used to carrying out the government affairs that has become the regional authorization in the province or district level, i.e., including the compulsory affairs and choices affairs according to the law regulation (Setiawan, 2017). The expenditures budget of West Sumatra Province, in general, can be seen from the table below:

Tabel.1 Expenditures Budget of West Sumatra Province in 2017 and 2018

\begin{tabular}{llrr}
\multicolumn{1}{c}{ No } & \multicolumn{1}{c}{ Item } & \multicolumn{1}{c}{$\mathbf{2 0 1 7}$} & \multicolumn{1}{c}{$\mathbf{2 0 1 8}$} \\
\hline $\mathbf{2}$ & Regional Expenditures & $\mathbf{6 . 1 7 2 . 5 6 5 . 9 8 7 . 0 2 0}$ & $\mathbf{6 . 6 9 6 . 6 4 1 . 4 1 0 . 3 0 0}$ \\
$\mathbf{2 . 1}$ & Indirect Expenditures & $\mathbf{4 . 2 0 1 . 6 7 5 . 0 8 4 . 3 0 0}$ & $\mathbf{4 . 0 0 8 . 2 8 1 . 8 0 1 . 4 2 9}$ \\
$\mathbf{2 . 1 . 1}$ & Employee Expenditures & 2.384 .645 .273 .288 & 2.170 .711 .960 .679 \\
$\mathbf{2 . 1 . 2}$ & Grant Expenditures & 1.087 .253 .647 .645 & 860.483 .200 .000 \\
$\mathbf{2 . 1 . 3}$ & Equal Share expenditures & 706.674 .535 .263 & 810.513 .475 .000 \\
$\mathbf{2 . 1 . 4}$ & Financial Aid Expenditures & 17.796 .645 .330 & 93.017 .602 .750 \\
$\mathbf{2 . 1 . 5}$ & Unexpected Expenditures & 5.023 .657 .263 & 72.655 .563 .000 \\
$\mathbf{2 . 2}$ & Direct Expenditures & $\mathbf{1 . 9 7 1 . 2 8 8 . 1 7 6 . 8 7 8}$ & $\mathbf{2 . 6 3 4 . 1 7 7 . 6 0 2 . 3 4 4}$ \\
$\mathbf{2 . 2 . 1}$ & Employee Expenditures & 40.873 .233 .400 & 28.706 .330 .000 \\
$\mathbf{2 . 2 . 2}$ & Goods \& Services Expenditures & 1.035 .459 .987 .890 & 1.522 .215 .472 .075 \\
$\mathbf{2 . 2 . 3}$ & Capital Expenditures & 896.098 .098 .775 & 1.083 .255 .800 .269 \\
\hline
\end{tabular}

Sumber: APBD Sumatera Barat 2017 dan 2018

From the table.1 it is showed that the amount of expenditures budget getting increased insignificantly i.e., from 6.172 trillion rupiahs in the year 2017 becoming 6.696 trillion in the year 2018. As for the regional expenditure's composition consist of indirect expenditures was decreasing around 200 million rupiahs from 4.201 trillion rupiahs in 2017 becoming 4.008 trillion rupiahs in 2018. These decreasing expenditures of indirect budget were influenced by the decreasing of employee's expenditures budget that has the biggest allocation portion on the regional expenditures whereas from 2.384 trillion rupiahs in the year 2017 becomes 2.170 trillion rupiahs in the year 2018.

\section{Management of Public Budgeting in Indonesia}

From the table. 1 it is shown that the number of expenditures budgets getting increased insignificantly, i.e., from 6.172 trillion rupiahs in the year 2017 becoming 6.696 trillion in the year 2018. The regional expenditures composition consists of indirect expenditures, decreasing around 200 million rupiahs from 4.201 trillion rupiahs in 2017, becoming 4.008 trillion rupiahs in 2018. These decreasing expenditures of indirect budget were influenced by the decreasing of employee's expenditures budget that has the most significant allocation portion on the regional expenditures. In contrast, from 2.384 trillion rupiahs in 2017 becomes 2.170 trillion rupiahs in the year 2018. 
Budgeting is the activities plan that created as the financial form covering the estimated expenditures proposal in one period of time that later is developed to serve various purposes, including the financial control, the management plan and also the priority for funds users and respond to the public (Safarudin \& Basri, 2016). As part of the reformation in public sector management, the reform of the expenditures led to the government's budgeting system's change by involving public financial planning to estimate revenues and expenditures for a certain period (Prakoso, 2017). With the implementation of this reformation on financial Management, Indonesia's budgeting system applied the PBB, i.e., budgeting planning was based on performance or output/outcome (Parhusip, 2016, Sugiarto A and D Mutiarin, 2017). Further, PerformanceBased Budgeting gives the consequences to each allocation of the planned budget related to the level of services and expected reached result (Sudaryanti, 2013).

Following Law number 17 the year 2003 about State Financial article 14 point (2) stated: " Budgeting and working plan that is arranged by the Minister/Chief of organization, was organized based on work achievement that will be reached." In this case, in doing budget planning, the government must use a Performance-Based Budgeting system (Parhusip, 2016). Further, strengthen by Government Regulation No. 21 the year 2004. In contrast, the State Ministry/Organization are compulsory to arrange the budget based on the performances indicators, standard of cost and performances evaluation so to create those things according (Silalahi, 2013), the budgeting planning should be done through several stages as follows: determining the organization strategies (vision and mission), purpose making, determining the activities, evaluation and decision making. According (Safaruddin \& Basri, 2016), the benefits that are gained from the application of Performances-Based Budgeting by regional government consist as follows:

1) To Society

It is a development statement that is stated by the regional government to answer each need, aspiration of the Society in order to reach the people's prosperity.

2) To Head of Regional area as the Management

It is as a management tool to control and lead every regional government activity to follow the plan.

3) To the State employee and Task Force As a tool to enhance the task force to be more selective in planning based on the regional priority scale, main task, function, purposes, targets. It guarantees the activities synchronization and avoids lapping activities.

4) To Stakeholder that are represented by the Regional House of Parliament

As a communication media and responsibilities on the success and the failure of local government missions to reach the purposes and target.

\section{Spending Review in Indonesia}

According to Robinson (2013), Spending Review is the government's effort in budget efficiency by looking at the expenditures that will be used as the local expenditures (Prakoso, 2017). In general, the definition of spending review is one of the fiscal reformation instruments to create a fiscal room by reducing or re-allocating the expenditures budget caused by the changes on the priority allocation and increasing demand services or increasing performances indicator. So, it can be said that spending review was a part of the Performance-Based budgeting system since the information result that was presented will be used in the decision-making process to determine to budget (Parhusip, 2016). Further spending review has two primary purposes, i.e., giving full control to the stakeholders in state policymaking on the government's expenditures and prioritizing public funds spending (Prakoso, 2017). Then, Robinson (2013) stated that spending review could be classified into 2 (two) categories as follows:

1) Economizing on Efficiency, this effort will be made by reducing the expenditures by changing the way in giving services by reducing the cost of services implementation, but the quality services given remained the same.

2) Strategically Economizing. It was done by cutting the budgets that should be allocated to 
Society

The purposes were to prevent the inefficiency usage of budgets by making identification on the program/activities, so it will not be repeated in the next budget, identify the potential of a fiscal room, to do the measurements of government budgets from the economic aspects or Efficiency or effectively (Parhusip, 2016). The primary method that can be used in doing the spending review according to (Schiavo-Campo, 1999: Curristine, 2005), for example, is benchmarking, performances, and evaluation measurements (Parhusip. 2016). While in Indonesia itself, the methods to do the spending review on the budget can be seen as follows:

1) Allocation Review, to identify the fiscal room potential by identifying the inefficiency indication, duplication, and budget identification, so the activities or the program not being repeated (einmaleg).

2) Review the target and performances indicator. This is by making efforts to do grouping on similar units to be known the best performances. From the unit within one group of similar units and measure the difference between one unit's performances with the best unit as inefficiency or usually known as benchmarking method.

3) Analysis on Need Deviation This is the method to analyze the needs deviation by calculating the deviation between realizing the task force unit's operational expenditures and the average of operational spending realization in one year (Parhusip, 2016).

\section{Performance Based Budgeting (PBB)}

is the output or working achievement from the activities done with the budgeting planning orientation that leads to effectiveness, efficiency, and economy (Pratama et al., 2018). While according to Sancoko (2008), the principal of Performance-Based Budgeting is the budget related to the state expenditures with the expected result (output and outcome) (Kurrohman, 2013). PBB is the budgeting model focusing on resource allocation based on program/activities (Prakoso, 2017). PBB was made to create efficiency, effectiveness, and accountability for public budgeting planning, with output and outcome according to the development priority scale. Each budget expenditure can be done with full responsibility to the public transparently (Kurrohman, 2013). According to the Government Law no.58 the year 2005 on Regional Financial Management, the regional expenditures are prioritized to protect and improve the life quality of Society in order to fulfill the local duty in the form of improving the basic services, education, health, social facility, and decent public facility and also developing social security system (Juanda \& Heriwibowo, 2016). According to Kong (2005), there are three types of performances measurement orientation in budgeting (Prakoso, 2017) as follow:

1) Focusing on the resources, whereas the government budgeting has focused only to measure the input resources performances, i.e., financial or other resources.

2) Focusing on the organization, whereas the government budgeting also focuses on the process performances and the organization's result is including financial, services, and program and activities.

3) Focusing on the customer. The government budgets emphasize the satisfaction, quality of services, and result.

So, the meaning in general, Performance-Based Budgeting is the budgeting system that has focused on the relation between the funds and the expected result, including the result achievement efficiency that later will encourage the transparency, efficiency, effectiveness, and accountability principle (Kurrohman, 2013). Performance-Based budgeting aims to enhance public expenditures' effectiveness and efficiency by connecting the budgeting on public sector organizations with the output that needs to be reached through performance information usage 
(Robinson \& Last, 2009). Then according to Supervision Directorate on Regional Financial Management, the purpose of Performance-Based budgeting is as follows:

1) To links between funds and target performance.

2) Increasing the efficiency and transparency on the implementation of budgeting management.

3) Increasing the accountability and flexibility in term of the budgeting management implementation.

According to Bappenas (2009), the performances indicators can give an overview about the things that want to be measured and to determine whether the expected result has been reached, whereas the indication measurements as a review instrument on the government expenditures as follows (Nanda \& Darwanis, 2016):

1) Input is the performance measurement based on the funding, human resources, material, time, technology, and other measurements used to implement the program and activities

2) Output is activity/service/product that resulted from the program and activities following the input.

3) Outcome is the performance indicator is based on goods/services that resulted from the program and activities following the input.

4) Benefit is the performance indicator based on the beneficial level that Society and government.

5) Impact

Is the performance indicator based on the macro condition's implication that should be reached from that benefit

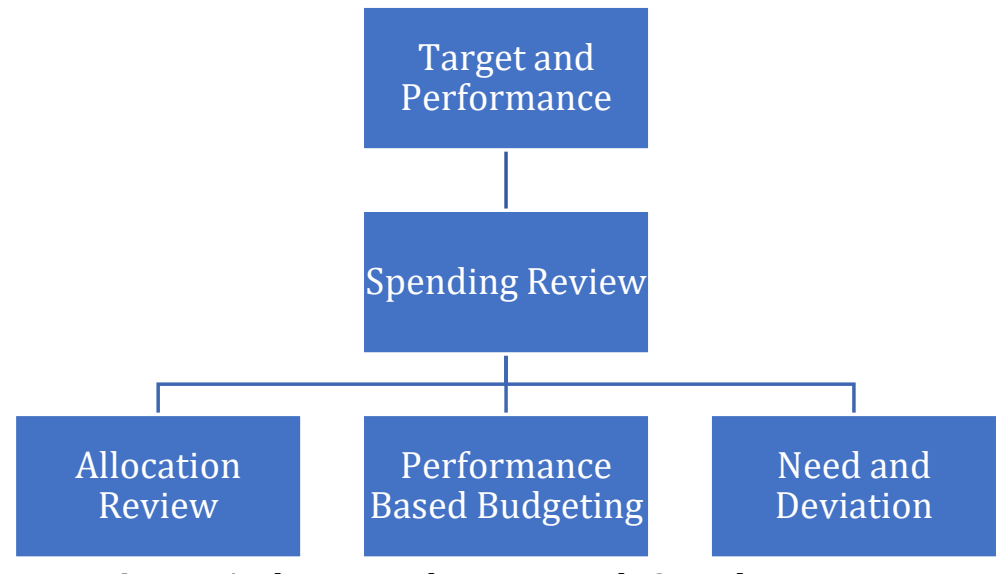

Figure.1 Theoretical Framework Spending Review

\section{RESEARCH METHOD}

According to (Anggito \& Setiawan, 2018), this article uses qualitative research that qualitative research is data collection on a natural base rather than interpreted further and interprets that phenomenon. According to (Creswell 2015), this qualitative research is because specific research problems need to be identified deeply and need a more detailed understanding of the problems. There are problems in implementing spending review to identify the quality of regional government management on expenditures budget need more in-depth and comprehensive understanding to determine the essence/contexts of the object of the problems that cannot be gained from quantitative research.

Further, the research data were gained from the study of literature through the online or offline method in the form of documents, literature, article, journal, documentation, activities publication file, link on the internet, and other methods that related to the objects of the research and support the research analysis. Then, the technique of qualitative data research is done through the stage of data codification, data presentation, and concluding (Afrizal, 2015). In this 
research, the analysis data technique is done through the research data codification stage, data presentation, and research result, giving the research conclusion that will later interpret the research result.

\section{RESULT AND DISCUSSION}

According to Ministry of Home Affairs Regulation (Permendagri) No. 13 the year 2006 about the Guidance on Regional Financial Management, which has been revised with Permendagri No. 21 Year 2011, explained that the structure of State Budget is integrated. Overall activities plan and financial consist of the regional revenue, regional expenditures, and regional financing. Judging from the aspect of regional expenditures, then it can be categorized into two types as follows:

1) Indirect Expenditures is the spending that is not related to the program and activities.

2) Direct Expenditures is the spending that is directly related to the program and activities.

For West Sumatra province, the regional expenditures budget by the year 2017-2018 was increased, and the expenditures budget was dominated by indirect spending.

The regional expenditures of West Sumatra province year 2017 amounted to 6.17 trillion increased in 2018 for 6.69 trillion. For indirect spending (BTL) was decreased, i.e., the year 2017 amounted to 4.20 trillion became 4.01 in 2018, while direct spending increased, i.e., in 20171.97 trillion became 2.63 trillion in the year 2018. There was suspicion for spending budget mark-up, making the APBD because employees' spending is usually fixed and within the measurement. On the other side, the regional financial ability by comparing the expenditures budget if the expense amount were much more significant than regional revenues in APBD so in consequences it will create expenditures deficit every year (Sigiro, 2016). To press down the possibility of a much bigger deficit, the regional government should try its best to efficiently allocate the regional spending budget as stated in the APBD

\section{Spending Review Regional Expenditures}

Spending review, according to Robinson (2013), was a tool to enhance the improvement on the expenditures priority (allocation efficiency) that can be used in order to secure the reallocation process of the government resources in giving the full public services (Prakoso, 2017). Further, according to Dunn (2015), spending review is the best way in the frame of fiscal consolidation as an evaluation method that can be used by the government for public policy analysis upon the regional government expenditures budget based on Spending-Based Performances (PBB) as follows:

\section{Allocation Review}

The allocation review is done by viewing as a whole from budget allocation and the regional expenditures realization that consist of operational expenditures, capital expenditures, and other expenditures. A description of the regional expenditure allocation of West Sumatra province in the year 2017 and 2018 shown in the following table:

Table.2 Realization of Regional Expenditures Budget West Sumatra Province The year 2017 and 2018

\begin{tabular}{|c|c|c|c|c|c|c|}
\hline & \multicolumn{2}{|c|}{ Operational Expenditures } & \multicolumn{2}{|c|}{ Capital Expenditures } & \multicolumn{2}{|c|}{ Other Expenditures } \\
\hline & Ceiling budget & Realization & Ceiling budget & Realization & Ceiling budget & Realization \\
\hline $\begin{array}{l}\text { Allocation } \\
\text { Regional } \\
\text { Expenditures } \\
\text { the year } 2017\end{array}$ & 1.971.288.176.878 & 1.565.878.373.873 & 896.098.098.775 & 820.897 .880 .122 & 70.787 .890 .400 & $50.989 .079 .07 \mathrm{C}$ \\
\hline $\begin{array}{l}\text { Allocation } \\
\text { Regional } \\
\text { Expenditures } \\
\text { the year } 2018\end{array}$ & 2.634.177.602.344 & 2.497.098.564.765 & 1.083.255.800.269 & 800.986 .383 .200 & 100.898 .904 .092 & 80.094 .500 .203 \\
\hline
\end{tabular}


The above table shows that on the government's expenditures budget for the year 2017 of West Sumatra province, they allocated the operational expenditures amounted 1.9 trillion. The realization was about 1.5 trillion. Hence, there is still a balance of around 500 billion of operational expenditures budget that has not been absorbed.

For the year 2018 budget, the operational budget allocation was set around 2.6 trillion, and the realization was only 2.4 trillion, so there were remaining unabsorbed funds amounted to 200 billion. The allocation for capital expenditures in the year 2018, around 1 trillion, and the realization were about 800 billion. Hence there was a remaining balance of about 200 billion. For other expenditures in the year 2018, the available budget ceiling amounted to 100 billion and the realization only about 50 billion. Based on the allocation review that was done upon the realization of regional expenditures budgets of West Sumatra province in the years 2017 and 2018, it can be acknowledged that the efficiency of the expenditure in the years 2017 and 2018 quite economical.

\section{Review on Indicator and Performances}

The review on the expenditures budgets was done by grouping each similar unit known as the best performances in one unit within one similar unit group. It measures the difference between the performance of one unit with the best performances. It is generally known as the term benchmarking method (Parhusip, 2016). The grouping of similar units was done to keep the quality of expenditures budget, i.e., on education and health care expenditures as an investment effort for human resources development. Spending review on budget management can benefit as a whole. However, it was not being found how big the influence of spending review upon the improvement of output quality or services (Parhusip, 2016). Should there be improvements in services or output, it can be examined from the LAKIP of each organization (Parhusip, 2016). For spending review on indicator and performances aspects can be seen from the expenditures for basic services to Society in the field of education and health care at the West Sumatera province as follows:

Table.3 the expenditures Budget on Health Care and Education Services of West Sumatra province the year 2017

\begin{tabular}{llll}
\hline Target & Budget & Budget Realization & Performance Result \\
\hline Increasing Health care quality & 145.633 .604 .409 & 112.534 .487 .571 & $96.94 \%$ \\
Increasing Education quality & 2.162 .545 .644 .698 & 1.779 .026 .153 .007 & $70.05 \%$ \\
\hline
\end{tabular}

Source: LAKIP Sumbar Province 2017

The provided budget to improve health care and education in West Sumatra province were quite significant from the above table. The health care budget around 145 billion, and the realization was 112 billion or almost close to perfection, with the performance achievement index around $96.94 \%$. While for education budgets, the amount was enormous, i.e., 2.1 trillion and the realization that only 1.77 trillion or performances achieved $70.05 \%$. In general, to develop human resources on education services expenditures, the budget's absorption was relatively high compared to health care services. However, on the performance achievement were contrary, the health care services owned a much higher performance achievement index.

\section{Deviation Need Analysis}

The deviation need analysis is done with analysis on the need deviation by counting the deviation between operational expenditures and the average of operational expenditures realization within a one-year budget (Parhusip, 2016). In other words, to measure the real need 
for operational expenditures according to the needs and identify the saving potential. For operational expenditures within regional expenditures were allocated for staff expenditures, goods and services expenditures, interest, grants, and social aid.

\section{Performance Based Budgeting (PBB) on Education and Health Services}

PBB is the budget that connects state expenditures and the expected result (output and outcome) (Kurrohman, 2013). According to Kong (2005), there was 3 type of performance measurement orientation in budget planning as follows:

a) Focused on resources

The government budget has a target to measure the input resources performance like financial or other resources, as for the source of funds in basic services through health care and education field at the West Sumatra province. For health care services from the ceiling budget, the year 2017 around Rp. 145.633.604.409, and it can be realized around Rp. 112.534.487.571 or performance achievement around $96.94 \%$, while the ceiling budget amounted to $\mathrm{Rp}$ for education services. 2.162.545.644.698 and the realization amounted to Rp. 1.779.026.153.007 or performance achievement around 70.05\%.

b) Focused on organization

The government budget also focused on the organization's performance process and resulted, including finance, services, program, and activities. For the program services and activities in the health care field with the realizations can be seen from the following details:

Table.4 Target and Performance Realization the year 2017 Health Care Department West Sumatra province

\begin{tabular}{|c|c|c|c|c|c|}
\hline No & $\begin{array}{l}\text { Strategically } \\
\text { Target }\end{array}$ & Performances Indicator & $\begin{array}{l}\text { Performance } \\
\text { Target }\end{array}$ & Realization & Achievement $\%$ \\
\hline \multirow[t]{2}{*}{1} & $\begin{array}{l}\text { The improvement } \\
\text { in the quality of } \\
\text { Health care } \\
\text { services }\end{array}$ & $\begin{array}{l}\text { The number of accredited Health } \\
\text { care society center }\end{array}$ & 56,00 & 103,00 & 198,93 \\
\hline & & Number of accredited Hospitals & 3,00 & 12,00 & 400,00 \\
\hline \multirow[t]{3}{*}{2} & $\begin{array}{l}\text { The improvement } \\
\text { in Society Health }\end{array}$ & $\begin{array}{l}\text { Prevalence Stunting in children } \\
\text { under } 5 \text { years old }\end{array}$ & 30,50 & 18,60 & 163,98 \\
\hline & & $\begin{array}{l}\text { Percentage of maternity woman } \\
\text { in getting the lab our services } \\
\text { according to the standard at } \\
\text { health facility }\end{array}$ & 79,00 & 80,37 & 101,73 \\
\hline & & $\begin{array}{l}\text { Percentage neonatal first visit } \\
\text { (KN1) according to the standard }\end{array}$ & 81,00 & 85,85 & 105,99 \\
\hline 3 & $\begin{array}{l}\text { The improvement } \\
\text { in prevention and } \\
\text { disease control }\end{array}$ & $\begin{array}{l}\text { Number district/city that } \\
\text { reached } 80 \% \text { complete basic } \\
\text { immunization on children by age } \\
0-11 \text { months }\end{array}$ & 9,00 & 11,00 & 122,22 \\
\hline 4 & $\begin{array}{l}\text { The increasing } \\
\text { health insurance } \\
\text { participants }\end{array}$ & $\begin{array}{l}\text { Percentage of society who owns a } \\
\text { health insurance }\end{array}$ & 70,00 & 70,59 & 100,56 \\
\hline \multirow[t]{3}{*}{5} & $\begin{array}{l}\text { The improvement } \\
\text { of organization } \\
\text { management }\end{array}$ & $\begin{array}{l}\text { Percentage of physical realization } \\
\text { achievement on the } \\
\text { program/activity's } \\
\text { implementation }\end{array}$ & 100,00 & 98,47 & 98,47 \\
\hline & & $\begin{array}{l}\text { Percentage of financial } \\
\text { realization on program/activities } \\
\text { implementation }\end{array}$ & 95,00 & 90,65 & 95,42 \\
\hline & & $\begin{array}{l}\text { The evaluation result on } \\
\text { performances accountability }\end{array}$ & $\mathrm{B}$ & & \\
\hline
\end{tabular}


For education programs, the program realization can be seen on the following table:

Table.5 Target and Performance Realization the year 2017 Health Department of West Sumatra province

\begin{tabular}{|c|c|c|c|c|c|}
\hline No & Strategical Target & Performance Indicator & Target & Realization & Achievement \\
\hline \multirow[t]{5}{*}{1} & \multirow{5}{*}{$\begin{array}{l}\text { Improving access and } \\
\text { education equality }\end{array}$} & Gross Enrollment Ratio & 85,52 & 86,02 & 100,58 \\
\hline & & $\begin{array}{l}\text { Of Senior High School. } \\
\text { net enrollment rates of } \\
\text { Senior High School }\end{array}$ & 73,60 & 73,73 & 100,18 \\
\hline & & $\begin{array}{l}\text { Number of drop out } \\
\text { student in Senior High } \\
\text { School }\end{array}$ & 0,78 & 0,74 & 94,87 \\
\hline & & $\begin{array}{l}\text { Number of drop out } \\
\text { student in SMK }\end{array}$ & 0,61 & 058 & 95,08 \\
\hline & & $\begin{array}{l}\text { Number of discontinuing } \\
\text { students from Junior High } \\
\text { to Senior High School }\end{array}$ & 3,60 & 2,71 & 132,84 \\
\hline \multirow[t]{4}{*}{2} & \multirow{4}{*}{$\begin{array}{l}\text { The improvement on } \\
\text { relevant quality and } \\
\text { education competition }\end{array}$} & $\begin{array}{l}\text { The number of Senior high } \\
\text { School/MA's graduate }\end{array}$ & 97,35 & 99,63 & 102,34 \\
\hline & & $\begin{array}{l}\text { Number of Senior high } \\
\text { graduate students that } \\
\text { were accepted at the } \\
\text { university }\end{array}$ & 45,23 & 45,11 & 99,73 \\
\hline & & $\begin{array}{l}\text { Number of SMK graduate } \\
\text { student }\end{array}$ & 97,30 & 98,82 & 101,56 \\
\hline & & $\begin{array}{l}\text { Number of SMK students } \\
\text { that were accepted at the } \\
\text { university }\end{array}$ & 32,00 & 31,16 & 97,38 \\
\hline 3 & $\begin{array}{l}\text { Improving the services } \\
\text { on education } \\
\text { management }\end{array}$ & $\begin{array}{l}\text { Percentage of minimum B } \\
\text { accredited Middle } \\
\text { school/SLB }\end{array}$ & 73,67 & 73,67 & 100,00 \\
\hline \multirow[t]{3}{*}{4} & $\begin{array}{l}\text { Improving the } \\
\text { competency and }\end{array}$ & $\begin{array}{l}\text { Result of SLB teacher's } \\
\text { competency test }\end{array}$ & 59,93 & 65,18 & 108,76 \\
\hline & $\begin{array}{l}\text { professionalism of } \\
\text { teachers and education }\end{array}$ & $\begin{array}{l}\text { Result of education } \\
\text { expert's competency }\end{array}$ & 16,67 & 19,19 & 115,00 \\
\hline & staff & $\begin{array}{l}\text { Result of SMA/SMK } \\
\text { teacher's competency }\end{array}$ & 65,18 & 62,12 & 95,31 \\
\hline 5 & $\begin{array}{l}\text { Implementing the } \\
\text { character education } \\
\text { through education } \\
\text { services }\end{array}$ & Student Integrity & 66,00 & 68,27 & 103,44 \\
\hline 6 & $\begin{array}{l}\text { Improving special } \\
\text { education and services }\end{array}$ & $\begin{array}{l}\text { Improvement of special } \\
\text { education services }\end{array}$ & 68,42 & 73,68 & 107,69 \\
\hline \multicolumn{3}{|c|}{ Total } & & & 105,05 \\
\hline
\end{tabular}

Source: Education Agency of Sumatera Barat Province The year 2017

\section{Focused on customers}

It means the government budget is stressed out on the performance step (satisfactory, quality services, and result). From that description, it was known that the society satisfaction in West Sumatra province for the health care services the year 2017 was around 85.13\%. Society satisfaction with education services around $87.85 \%$.

\section{CONCLUSION}

Based on the result and discussion during the research, the conclusions will be as follows: 
(1) In general, the condition of regional government expenditures budget at the West Sumatra province has increased from 2017 amounted $\mathrm{Rp} 6.172 .565 .987 .020$ became Rp.6.696.641.410.300 in the year 2018. The budget was used to fulfill the staff expenditures with an average of 55.78\% from the total budget in 2017-2018;

(2) Government employee expenditures budgets of West Sumatra province decreased from Rp. 2.384.645.273.288 into Rp. 2.170.711.960.679 in 2018, hence it creates the efficiency on employee's expenditures budget around 200 billion in two the year budgeting the years;

(3) The review result and allocation that has been done upon the regional expenditures budget realization, there were budget efficiency in the year 2017 and 2018;

(4) For indicator and performance review on basic need through health care services and education whereas the realization of health care budget was Rp. 112.534.487.571 with the performance achievement around 96.94\%, while for education services, the budget realization around Rp. 1.779.026.153.007 with the performance result around 70.05\%;

(5) The deviation needs analysis showed that in 2017 and 2018, the West Sumatra province's government budget has an average of need deviation with the allocation of regional expenditures budget around $15.56 \%$.

\section{ACKNOWLEDGEMENT}

The main author is grateful to the Head of MIP (MGAA) Department - UMY, Dr. Suswanta, M. Si. and my student of MIP (MGAA) UMY - Aqil Teguh Fanani, who have encouraged this manuscript to be better and become an output as a joint work of MIP lecturers and students.

\section{REFERENCE}

Afrizal. (2015). Metode Penelitian Kualitatif: Sebuah Upaya Mendukung Penggunaan Penelitian Kualitatif dalam Disiplin Ilmu. Jakarta: Raja Grafindo Persada.

Anggito, A., \& Setiawan, J. (2018). Metodologi Penelitian Kualitatif. (E. D. Lestari, Ed.). Jawa Barat: CV. Jejak Publisher.

Astutiningrum, A., Djamhuri, A., \& Prihatiningtias, Y. (2014). New Institutional Theory: Implementasi Anggaran Berbasis Kinerja Menuju Organisasi Yang Kompetitif Dan Berorientasi Pasar. Jurnal Reviu Akuntansi Dan Keuangan, 4(2), 595-606. https://doi.org/10.22219/jrak.v4i2.4944

Creswell, J. (2015). Penelitian Kualitatif dan Desain Riset: Memilih di antara lima pendekatan (3rd ed.). Yogyakarta: Pustaka Pelajar.

Dwiputrianti, S., \& Suharsini, S. (2012). Terhadap Efisiensi , Efektifitas Dan Akuntabilitas Pada Pusat Pendidikan Dan Pelatihan Kementerian Dalam. Jurnal STIA LAN Bandung, 9(3), 309329.

Juanda, B., \& Heriwibowo, D. (2016). Melalui Reformasi Kebijakan Belanja Daerah Berkualitas (Decentralization Fiscal Consolidation through Policy Reform of Local Quality Spending). Jurnal Ekonomi \& Kebijakan Publik, 7(1), 15-28.

Kurrohman, T. (2013). Evaluasi penganggaran berbasis kinerja melalui kinerja keuangan yang berbasis. Jurnal Dinamika Akuntansi, 5(1), 1-11.

Ledo, D., \& Ayem, S. (2017). Pengaruh Aspek-Aspek Manajemen Keuangan Daerah Terhadap Transparansi Pengelolaan Keuangan Daerah (Studi Kasus Pada SKPD Kota Yogyakarta). Jurnal Kajian Bisnis, 25(2), 226-234.

Luthfia, M., \& Siregar, B. (2016). How Do Governments Spend Their Public Spending? Economia, $12(2), 135-145$.

Nanda, R., \& Darwanis, D. (2016). Analisis Implementasi Anggaran Berbasis Kinerja Pada Pemerintah Daerah. Jurnal Ilmiah Mahasiswa Ekonomi Akuntansi (JIMEKA), 1(1), 327-340.

Nurfauziya, A., Prakosa, K. B., \& Kusuma, H. (2018). Dampak Desentralisasi Fiskal Terhadap Kesehatan Masyarakat ( Studi Di Provinsi Daerah Istimewa Yogyakarta ). Dampak Desentralisasi Fiskal Terhadap Kesehatan Masyarakat (Studi Di Provinsi Daerah Istimewa Yogyakarta) Ahada, 5(2), 191-209. 
Octariani, D. (2017). Good Governance, Performance Based Budgeting and SKPD Budget Quality SKPD (The Case of a Structural Model Approach). Jurnal Kebijakan Dan Administrasi Publik, 21(2), 117-131. Retrieved from https://journal.ugm.ac.id/jkap

Parhusip, B. (2016). Analisis Implementasi Spending Review pada Kementerian Negara/Lembaga Tahun 2013-2015. Jurnal Kajian Ekonomi Dan Keuangan, 20(3), 191-211.

Prakoso, R. (2017). Indonesia Spending Reviews in the Context of Financial Management Reform. (December).

Pratama, N. D., Abdurahim, A., \& Sofyani, H. (2018). Determinan Efektivitas Implementasi Anggaran Berbasis Kinerja Dan Penyerapan Anggaran Di Pemerintah Daerah. Jurnal Reviu Akuntansi Dan Keuangan, 8(1), 9. https://doi.org/10.22219/jrak.v8i1.23

Rachmandiansyah, A. (2015). Analisis Spending Review Sebagai Keputusan Manajerial Sesuai Surat Edaran Direktur Jenderal Perbendaharaan Nomor SE-2 / PB / 2015. Jurnal Ilmiah Mahasiswa FEB, 6(2), 1-10.

Robinson, M. (2013). Spending review. OECD Journal on Budgeting, 13(2), 81-122.

Robinson, M., \& Last, D. (2009). Analisis Implementasi Anggaran Berbasis Kinerja Pada Pemerintah Daerah (Studi Deskriptif Pada Dinas DPKKD Kabupaten Aceh Selatan). Washington: International Monetary Fund.

Safaruddin, \& Basri, S. (2016). Pengaruh Penerapan Anggaran Berbasis Kinerja Terhadap Akuntabilitas Publik Pada Instansi Pemerintah (Studi Pada Badan Pengelola Keuangan Dan Aset Daerah Kota Kendari). Jurnal Akuntansi Dan Keuangan, 1(1), 93-105. Retrieved from http://ojs.uho.ac.id/index.php/JURNALAKUNTANSIKEUANGAN/article/view/2026

Sari, N. M. D. P., \& Mustanda, I. K. (2019). Pengaruh Ukuran Pemerintah Daerah, Pendapatan Asli Daerah Dan Belanja Modal Terhadap Kinerja Keuangan Pemerintah Daerah. E-Jurnal $\begin{array}{llll}\text { Manajemen Universitas } \quad \text { Udayana, } & 8(8), & \end{array}$ https://doi.org/10.24843/ejmunud.2019.v08.i08.p02

Setiawan, D. (2017). Fenomena Plypaper Efect Pada Belanja Daerah Kabupaten/Kota Di Indonesia. EKUITAS (Jurnal Ekonomi Dan Keuangan), 1(2), 220. https://doi.org/10.24034/j2 5485024.y2017.v1.i2.2062

Silalahi, S. P. (2013). Pengaruh Anggaran Berbasis Kinerja, Sistem Akuntansi Keuangan Daerah, Dan Sistem Informasi Pengelolaan Keuangan Daerah Terhadap Penilaian Satuan Kerja Perangkat Daerah (STUDI PEMERINTAHAN DI KOTA DUMAI). Jurnal Ekonomi, 20(03), 1-20.

Sigiro, B. (2016). Responsivitas Anggaran ( Sebuah Refleksi dari Proses Penyusunan APBD. 571596.

Sudaryanti, D. (2013). Pengaruh Penganggaran Terhadap Kinerja Aparat Pemda Melalui Sistem Informasi Keuangan Daerah (Studi Kasus: Pemda Kab Kudus). Jurnal Ekonomi Dan Bisnis, 12(1), 11-24.

Sugiarto A and D Mutiarin (2017). Konsistensi perencanaan pembangunan daerah dengan anggaran daerah. Journal of Governance and Public Policy, Vol 4. No.1.

Verasvera, F. (2016). Pengaruh Anggaran Berbasis Kinerja Terhadap Kinerja Aparatur Pemerintah Daerah (Studi Kasus Pada Dinas Sosial Provinsi Jawa Barat). Jurnal Manajemen Maranatha, 15(2), 137-162.

Wijayanti, A. W., Rahman, M. R. K., \& Nurpratiwi, R. (2012). Perencanaan Anggaran Berbasis Kinerja di Kabupaten Pasuruan. Wacana, Jurnal Sosial Dan Humaniora, 15(3), 10-17. 